Society for the Anthropology of Work • Essential Labor

\title{
Business Always as Usual: Hypernormalization and Pandemic Labor
}

Alya Ansari, Mitch Hernandez

Published on: Jun 03, 2020

DOI: 10.21428/1d6be30e.cc25e869

License: Creative Commons Attribution 4.0 International License (CC-BY 4.0). 
We see today, across the Western ideological spectrum, a common tendency to speak of changing social and economic conditions in terms of establishing a new normal. This tendency finds immediate expression in the numerous pandemic op-eds, expert testimonials, and speculative thinkpieces making the virtual rounds. At the level of discourse, it underwrites the entrenchment of antilabor policies and practices. As we adjust to shelter-in-place and social distancing measures, it may seem as though we have fundamentally changed the way in which we interact with each other and with our work. Yet to speak of the pandemic solely in these terms-of sensationalized exception, of a radically novel state of existence-obscures the profound normalcy of the present moment, particularly with regard to the inequitable distribution of resources in our highly stratified capitalist society and the deplorable conditions of labor at the root of this inequity. Attuning ourselves to the labor practices and policies emerging amid the current crisis makes abundantly clear how the rhetoric of the new normal is being used to legitimize preexisting exploitative practices as necessary and essential to our survival. In so doing, proponents of the new normal work to insulate these policies and practices from criticism and resistance.

We want to suggest that the response to COVID-19 has not ushered in a radically new normal. Rather, the current milieu and the mainstream discourse around it serve to obscure the powerfully abnormal conditions of labor that have been forced upon the worker by neoliberal regimes. We are thus living in the hypernormal, defined by deceptions that facilitate continued assaults upon workers' rights and freedoms and that are enabled by a pandemic state of exception. In attempting to elaborate the concrete repercussions of hypernormality, we place the pandemic formulation of workfrom-home in relation to essential labor so as to reveal the warped conditions of pandemic labor as the warped conditions of labor generally speaking. In doing so, we demonstrate how accelerated neoliberal policy masks itself as something else under the auspices of the pandemic.

When we have no memory or little imagination of an alternative to a life centered on work, there are few incentives to reflect on why we work as we do and what we might wish to do instead. 
-Kathi Weeks

Pandemic labor feels bizarre, leading many to wonder how the large-scale experiment in working from home will play out. But it is important to place this labor in the context of its prepandemic expression and then to ask whether treating conditions of pandemic labor as emergent- novel enough to present previously unseen challengesis warranted. It is no less important to ask how might we understand work-from-home in relation to other forms of pandemic labor, such as "essential" work. Working from home during the pandemic is likely preferable to the alternative, and the best-case scenario for getting sick-having good health insurance, paid time off, and a reasonable boss - is an inconceivable luxury. for most. According to the U.S. Bureau of Labor Statistics, only 28.8 percent of workers were able, willing, and compensated for working from home during 2017 and 2018. These numbers are staggeringly low for categories of workers deemed essential-services (6.2 percent), production (4.4 percent), or transportation and material moving (3.0 percent). Work-from-home was also mostly inaccessible to workers who had not earned a high school diploma (4.2 percent), while lacunae in the data made it difficult to account for the likely significant effects of race and ethnicity. In short, work-from-home presents itself as a relative privilege when we acknowledge the dangers associated with the essential labor of socalled frontline workers. But this acknowledgement does not discount the exclusionary and exploitative nature of work-from-home. Unlike essential workers, however, workfrom-home laborers have been partially shielded from this reality by better compensation and by media narratives of the newness of work-from-home.

The danger of registering work-from-home as a privilege is that it obscures the more insidious machinations of an economic system that exploits everyone. There is no formulation that does a greater disservice to the campaign against labor exploitation than that of work-from-home, particularly given how this pandemic is throwing into relief how exploitative the system of labor really is even outside times of crisis. A willingness to accept such conditions of labor with the requisite note of protest-“Ugh, I just cannot do another Zoom meeting that could have been an email!"-is quietist.

The key lies in acknowledging that these conditions-all the more anxiety-inducing and isolating during quarantine or shelter-in-place-have also always been this way. In Karl Marx's terms, all workers are estranged from their labor by a process that extracts surplus. It's not just that we can't see the products of our labor-a factory worker on the production line only sees the component part that she is responsible for, not the 
assembled product that she was instrumental in creating-but also that we don't recognize the activity of our work as work. This estrangement is exacerbated when the workplace occupies the home. "Estrangement manifests itself not only in the result, but also in the act of production, within the activity of production itself," writes Marx (1992: 326). "The fact that labor is external to the worker [means] that he does not confirm himself in his work, but denies himself, feels miserable and not happy. . . . Hence the worker feels himself only when he is not working; when is working he does not feel himself. He is at home when he is not working, and not at home when he is working." Pandemic conditions or not, those now deemed essential workers would seem to be aware of their exploitation. But what of those working from home?

There's a ceremony around leaving the workplace that reinforces being "done" for the day. But it's harder to feel like you're free from your work-though, are we ever really_ free from work?-when the cubicle and the kitchen table have been superimposed. Despite the insistence of neoliberal capitalism that we should love our work, it's becoming clear to those laboring from home that this system isn't and hasn't been working for us, pun intended. Under neoliberalism, the labor ostensibly done solely in the public space of the workplace has made ever-increasing incursions into the private space of the home; this has long preceded the pandemic. What's happening today is that we are realizing that there's something deeply wrong with this configuration. Work-from-home confronts a critical mass of workers-workers who might not otherwise recognize this exploitative labor system as such-with the reality that the work doesn't end when you clock out. Kathi Weeks (2011) has already pointed out that the spheres of work and home are continuous and not discrete, but the widespread acknowledgment of this extension of one into the other may yet foster a kind of crosssector worker solidarity that seemed heretofore impossible. As workers from various sectors of the economy are transferred from office to home, pandemic labor conditions lay bare the exploitation to which they are subject; paradoxically, this presents an opportunity for solidarity. It might actually bring workers closer together.

You never want a serious crisis to go to waste.

-Rahm Emanuel 
Attuning to these exploitations will be easier if we are able to place them within the neoliberal constellation from which they originate. We must remain mindful of the ways in which our labor is repackaged and re-presented to us, and here the pandemic frame of reference does a disservice to a critical interrogation of capitalist exploitation. Neoliberal discourse depends on a facade of newness in order to cloak the intensification of its many unchanging forms of exploitation. The rhetoric of innovation and flexibility to which free-market advocates frequently appeal positions the market as "natural and inevitable, existing outside and beyond government," such that policymakers can merely respond to it. This has the secondary effect of rendering unjust policy decisions as necessary responses to market fluctuations. The work of economist Milton Friedman-who did not shy away from the moniker "neoliberal"illustrates this point. In the 1982 preface to his Capitalism and Freedom, Friedman (2002: xiv) proposes crisis as an ideal time for the advancement of neoliberal policy alternatives, so as to shake the inertia of "governmental arrangements." Yet what is presented as an alternative in fact reinscribes a "competitive order," which pits individuals against one another in a race to the top. Neoliberalism once represented a new form of capitalism, in which any pretense to assure social well-being was abandoned in the corporate interest. Today, however, this is a reality with which a battered and precarious working class is intimately familiar.

Any attempt to singularize the present moment as aberrant legitimizes already existing (and accelerating) worker injustices. Age-old battle lines are simply being fortified in the name of crisis response, as the pandemic normal marks the intensification of existing exploitative capitalist labor conditions. Essential workers might not have sensed a shift during the pandemic, for they are today no less encumbered by the pressures of work than before. Amazon's fractured relationship with its workforce prior to the outbreak of COVID-19 is telling of just that, while the 2020 May_Day strike demonstrates workers' keen awareness of and resistance to labor injustices. But workfrom-home now presents the remote workforce with the opportunity to build solidarity with their on-the-ground counterparts through an acknowledgement of shared conditions of labor. Workers-from-home enjoy certain privileges over those deemed essential, not least among them the ability to limit exposure to the virus. Yet recently_ enacted legislation might serve as a reminder, and, paradoxically, a point of solidarity for both essential laborers and workers-from-home at large corporations (with more than 500 workers) that they do not qualify for paid sick, nursing, or quarantine leave from either their employers or the state. 
The challenge that lies ahead of us, beyond the revelation of these continuities, is rethinking how we value our labor. Workers, despite their economic and material disadvantage relative to corporate employers, should seize the present moment to agitate for labor reform. Given that some workers are earning more on unemployment during the pandemic than they would if they returned to the workplace, there now exists the radical possibility of workers naming the inessentiality of work to conceptions of a happy life. Granted, unemployment benefits have been difficult to claim-and the brokenness of this system in the United States is another matter entirely_-but it is undeniable that there is space now, more than ever, for public discussions around the necessity of work in and as principle. The system of labor doesn't have to be any more than just that-a system in which you exchange your work for (fair and equitable) compensation, which doesn't compel you to love it or swear fealty to it or bind your worth as a human being to your productivity or efficiency, during a global health emergency or otherwise. That's a new normal we can get behind.

\section{Author Bios}

Alya Ansari is a PhD student in the Program in Comparative Studies in Discourse and Society at the University of Minnesota. Her work concerns the intellectual history of reason and the rationalization of late capitalist modernity, labor and absurdity, conspiracy theories, and trash/low aesthetics in cinema and visual culture.

Mitch Hernandez is a PhD student in the Program in Comparative Studies in Discourse and Society at the University of Minnesota. His work arises from a lived experience at the intersection of poverty and the postimmigrant identity. At the center of his thought are questions of neoliberalism: its dissemination, its material shaping of the world, its mythologies, as well as subjective life under its regimes of power.

\section{Preview Image}

Courtesy of Gilbert Mercier. 


\section{References}

Friedman, Milton. 2002. Capitalism and Freedom. Chicago: University of Chicago Press.

Marx, Karl. 1992. “Economic and Philosophical Manuscripts.” In Early Writings, translated by Rodney Livingstone and Gregor Benton. New York: Penguin Classics. Originally published in 1844.

Weeks, Kathi. 2011. The Problem with Work: Feminism, Marxism, Antiwork Politics, and Postwork Imaginaries. Durham, NC: Duke University Press. 